\title{
70 Years later - what do we have to learn from Dietrich Bonhoeffer in Latin America today?
}

\author{
Caldas, Carlos \\ Research Fellow at the Jesuit School of Philosophy and Theology \\ (Bolsista PNPD-CAPES), Belo Horizonte, Brazil. \\ crcaldas2009@hotmail.com
}

\begin{abstract}
The year 2015 marks the $70^{\text {th }}$ anniversary of the execution of the Christian theologian and Pastor Dietrich Bonhoeffer. His theological legacy has been of great importance in Latin America, for both ecumenical/liberationist theologians and Evangelical theologians alike. But the main question is: after so many years, is Bonhoeffer's theology still relevant in the Latin American theological context? In other words, 'Who is Dietrich Bonhoeffer for us - in Latin America - today?'
\end{abstract}

Keywords

Bonhoeffer studies, Latin American theology, Christology, Ecclesiology, Ecumenism

\section{Introduction}

German theology has always been important and influential in the centuries long construction of Latin American theology. This is a very interesting observation, given the fact that Latin American countries were not colonized by Germany. Christianity arrived in Latin American countries following the footsteps of the Conquistadores - in what are nowadays the Spanish-speaking countries in the Americas, but also in Brazil, which happens to be the Portuguese-speaking country of the continent.

The first expression of Christianity in Latin America was Roman Catholicism. Only in the $19^{\text {th }}$ century did Protestantism succeed in laying its roots in Latin American soil, due to the missionary work especially of American missionaries, and, to a lesser degree, of British missionaries as well. But as soon as theological education began in Latin America, there 
has been an influence of theology 'made in Germany'. Perhaps it is better to say, theology written in German, if one includes the theology of Karl Barth, in the Protestant tradition, and the theology of Hans Urs von Balthasar and Karl Rahner (a major influence for Gustavo Gutierrez for instance), in the Catholic tradition. Needless to say, the focus of this article is on Bonhoeffer, his influence on Latin American theology and the presentation of some points about the importance of Bonhoeffer's pastoral and theological legacy in Latin American theological theory and pastoral practice - this is the point itself of this presentation.

John De Gruchy once stated, 'Bonhoeffer has probably had more influence in South Africa on liberation and contextual theologies than any other European theologian in the $20^{\text {th }}$ century'. 'What De Gruchy declared about South Africa can also be said about the countries far away on the other side of the Atlantic, that is, Latin America.

Theological education among Protestants in Brazil began as early as the last two decades of the $19^{\text {th }}$ century, and once more, due to American missionary enterprise. At that time, theological education was only the reproduction of some text books used in the United States. Therefore, in the first decades of the late $20^{\text {th }}$ century there was a widespread use of Strong's Systematic Theology ${ }^{2}$ and after that, at least in Presbyterian circles, of Berkhof's Systematic Theology. ${ }^{3}$ These are very conservative systematic theologies. Nevertheless there were at least some news of recent developments of theology that had been taking place in Europe. Theological students in Latin American was hearing about the famous four B's of European Protestant theology: Barth, Bultmann, Brunner, and, last but not least, Bonhoeffer.

1 De Gruchy, John W. Bonhoeffer's Legacy: A New Generation. [Online]. Available: http://www.religion-online.org/showarticle.asp?title=72 [Accessed: 9 September 2015].

2 Augustus Hopkins Strong (1836-1921) was a Baptist American theologian. He wrote a Systematic Theology in three volumes that was used in the first half of the late $20^{\text {th }}$ century in Brazilian Presbyterian theological seminaries. The first edition of that work is of 1886. The newest edition is of 2014, published by CreateSpace Independent Publishing Platform.

3 Berkhof, Louis. Teologia Sistemática. 4a edição. São Paulo: Cultura Cristã, 2014. The first edition of Berkhof's Systematic Theology in Portuguese is of 1990. 
But at that time there were not yet any translations of those theologians. It was during the 1950's that the first attempts to formulate an indigenous or autonomous theology took place in the continent. Richard Shaull, an American Presbyterian missionary to Latin America - he first worked in Colombia, and afterwards in Brazil, and was a lecturer at the Presbyterian Theological Seminary in Campinas (Brazil) - spread the first seeds of what some years later would be a theological reflection done in Latin America by native Latin Americans.

Shaull, an alumnus of Princeton Theological Seminary, studied under Paul Lehmann. Lehmann, an American of German descent, was a close friend of Dietrich Bonhoeffer himself. ${ }^{4}$ Lehmann was Professor of Christian Ethics at Princeton, and Bonhoeffer's theology deeply influenced his own understanding of Christian Ethics and the role of the Christians in society. It is not surprising that after Princeton the young Shaull brought Bonhoeffer's theology to Brazil and taught his theology to his students. This was the beginning of the story of the influence exerted by Bonhoeffer on Latin American theologians. ${ }^{5}$

As early as 1952 the already mentioned Shaull, at that time teaching at the Presbyterian Theological Seminary in Campinas in São Paulo State, taught his students about some seminal Bonhoeffer works, e.g., The Cost of Discipleship, Life Together and, as mentioned by Anivaldo Padilha, Letters and Papers from Prison. In that very same year of 1952, Shaull started to speak about Bonhoeffer in his ecumenical meetings that took place in Sítio das Figueiras, Brazil. ${ }^{6}$

This was the beginning of the story of Bonhoeffer's influence in Latin America. Nevertheless, from now on our attention must be oriented toward the question of what is the importance of Bonhoeffer's theology in

4 See Schlingensiepen, Ferdinand 2010. Dietrich Bonhoeffer 1906-1945: Martyr, Thinker, Man of Resistance. London: T \&T Clark. p. 63-5, 70, 72, 94, 120, 230, 276.

5 Anivaldo Padilha, a very well-known ecumenical Methodist leader in Brazil, once told me (in a personal conversation that took place last year at São Paulo Methodist University) that it was about 60 years ago, when he was a young man, that he participated in several meetings under the leadership of Richard Shaull, who gave the participants typewritten copies of Bonhoeffer's texts, especially Letters and Papers from Prison.

6 Cf. Barreto Jr., Raimundo C. O movimento ecumênico e o surgimento da responsabilidade social no protestantismo brasileiro. Numen. Revista de estudos e pesquisa da religião. 21, V. 1, N. 1 e 2, 2010, p. 296. 
Latin America today. It seems to me that there are some important points that, 70 years later, are still of great relevance. This article does not have the presumptuous intention to have the last word on this matter. Rather, it is only the sharing of some personal impressions about it. But I think that 70 years after Bonhoeffer's execution we in Latin America have so much to learn from him and about him.

\section{The centrality of Christology in the theological reflection}

When one approaches any theologian in order to understand his or her theological thinking, it is very common to ask the question about the main characteristic(s) of that theology. So, what is the main characteristic or emphasis of Latin American theology? If we think in terms of Protestant theology in Latin America, it is wise to follow the late José Miguez Bonino in his book Faces of Latin American Protestantism. ${ }^{7}$ According to Miguez Bonino, Latin American Protestantism has several faces:

- The liberal face, with emphasis on the development of society through education;

- The evangelical face, with strong emphasis on conversion, isolation of the 'world', the central place of the Bible and a missiological emphasis in the whole of its thinking;

- The pentecostal face, with emphasis on the action of the Holy Spirit in the lives of the believers (Miguez Bonino proposes a keen critique of Pentecostalism, showing its incongruence between being a movement open to lay people, but with a hierarchical and pyramidal structure of power, detached from society but seeking political power);

- The ethnic Protestantism is the model of Protestantism that Brazilian sociologists of religion Antonio Mendonça e Prócoro Velasquez called 'Protestantism of Immigration'. It is formed by colonies of immigrants that came to Latin America and brought with them their Protestant faith (e.g., Waldensians from Italy who established themselves in Argentine and Uruguay and Lutherans from Germany who established themselves in Brazil and Chile). Miguez Bonino points to the fact that Evangelical Protestantism is more 'missionary' and the ethnic Protestantism is more 'pastoral'.

7 Grand Rapids: Eerdmans, 1997. 
None of these branches of Protestantism in Latin America has a definite Christological aspect (to be fair, Miguez Bonino understands ethnic Protestantism as Christological and Evangelical. Pentecostal Protestantism as Pneumatological, but he did not develop this interesting intuition further). Even though all of these possibilities are legitimate, what theology in Latin America can learn from and with Bonhoeffer, it seems to me, is a Christological theology. Bonhoeffer's Christology is Chalcedonian in its formulation. In addition, Bonhoeffer was wise enough to develop a theological ethics and an ecclesiology that are based on and derived from his understanding of the person and work of Christ. This is according to Bonhoeffer, in the essay Christ, Reality and Good. Christ, Church and the World.

The source of a Christian ethic is not the reality of one's own self, not the reality of the world. Neither is it the reality of norms and values. It is the reality of God that is revealed in Jesus Christ. This is the demand, before all others, that must honestly be made on anyone who wishes to be concerned with the problem of a Christian ethic. It places us before the ultimate and decisive question: With what reality will we reckon in our life? With divine grace or with earthly inadequacies? With the resurrection or with death? This question itself, which none can answer by their own choice without answering it falsely, already presupposes a given answer: that God, however we decide, has already spoken the revelatory word and that we, even in our false reality, can live no other way than from the true reality of the word of God. The question about ultimate reality already places us in such an embrace by its answer that there is no way we can escape from it. This answer carries us into the reality of God's revelation in Jesus Christ from which it comes. ${ }^{8}$

It is wise to remember what the German Bonhoeffer scholar Andreas Pangritz said. He said that in Bonhoeffer one can find a 'Christological concentration'. 'The Christology of Bonhoeffer is typically Lutheran, as he put his emphasis in Christ the Emmanuel, 'God with us', the Christ who

8 Bonhoeffer, Dietrich 2009. Ethics. Dietrich Bonhoeffer Works, Volume 6. Minneapolis: Fortress Press. p. 49.

9 Pangritz, Andreas 1999. 'Who is Jesus Christ for us Today?' In John W. de Gruchy (ed.). The Cambridge Companion to Dietrich Bonhoeffer. Cambridge: Cambridge University Press. p. 134-136. 
is here on earth (in contrast with a Reformed Christology which put its emphasis in Christ as the Second Person of the Trinity, the Christ above us in heaven as the Lord of the universe - 'Christ the King'). Christology is vital in any Christian theology. So it is not surprising that Christology is very important in the fabric of Latin American Theology of Liberation. Therefore, it is not a coincidence that Bonhoeffer had exerted influence on some Latin American theologians, e.g., Gustavo Gutierrez, ${ }^{10}$ Jon Sobrino, ${ }^{11}$ Juan Luis Segundo, ${ }^{12}$ and Frei Betto (in some of his Letters from Prison).$^{13}$ Catholic scholars do not always like to admit that, but nevertheless it is still true that Bonhoeffer already anticipated some intuitions of the Theology of Liberation. ${ }^{14}$

Evangelical Christology also has a lot to learn from Bonhoeffer's Christology. There is a tendency in some Evangelical circles of Latin America to understand Christology in a very different way: the so called 'traditional' Protestants (e.g., Presbyterians) by and large understand Christology in a quite orthodox way, but the result is one that Christ is absent from the

10 The Power of the Poor in History. Eugene: Wipf \& Stock, 2004 (previously published by Orbis Books, 1983).

11 Christology at the Crossroads. A Latin American Approach. Eugene: Wipf \& Stock, 2002 (previously published by Orbis Books, 1978).

12 Teologia aberta para o leigo adulto. São Paulo: Loyola, 1976.

13 Cartas da prisão. Rio de Janeiro: Civilização Brasileira, 1977. The influence of Bonhoeffer on Frei Betto can be seen in the title itself of his (Frei Betto's) book: Cartas da prisão means Letters from prison in Portuguese.

14 It can be clearly seen, for instance, when Bonhoeffer speaks about the necessity and the importance of seeing life from the underside of history: 'It remains an experience of incomparable value that we have for once learned to see the great events of world history from below, from the perspective of the outcasts, the suspects, the maltreated, the powerless, the oppressed and reviled, in short form the perspective of the suffering [...] that we come to see matters great and small, happiness and misfortune, strength and weakness with new eyes; that our sense for greatness, humanness, justice and mercy has grown clearer, freer, more incorruptible; that we learn indeed that personal suffering is a more useful key, a more fruitful principle than personal happiness for exploring the meaning of the world in contemplation and action. But this perspective from below must not lead us to become advocates for those who are perpetually dissatisfied. Rather, out of a higher satisfaction, which in its essence is grounded beyond what is bellow and above, we do justice to life in all its dimensions and in this way affirm it.' Bonhoeffer, Dietrich 2010 Letters and Papers from Prison. Dietrich Bonhoeffer Works, Volume 8. Minneapolis: Fortress Press. p. 52. This emphasis on 'see the great events of world history from below' would 'reappear', so to speak, in Latin American Theology of Liberation, roughly a quarter of a century after Bonhoeffer. 
daily lives of people. Besides, in Latin America, especially in Brazil, some Neopentecostal preachers present Christ as a sort of 'Genius of the Lamp', a mighty celestial being that is obliged to attend all requests of those who claim his help - if they give their tithes and offerings to the church... ${ }^{15}$ Contrary to this poor understanding of Christology, Bonhoeffer states in his essay 'Church and World': 'Christ is the centre and power of the Bible, of the church, of theology, but also of humanity, reason, justice, and culture ...To Christ everything must return; only under Christ's protection can it live'. ${ }^{16}$

It is against such a strange backdrop that I understand that theology in Latin America, especially that kind of theology done by traditional Protestants, Pentecostal and Neopentecostals, needs urgently to learn from Bonhoeffer's Christology. Perhaps the Christological accent of the theology of Bonhoeffer might be a sound corrective to some forms of Neopentecostal theology - for instance, the huge Universal Church of the Kingdom of God/Igreja Universal do Reino de Deus, which has a strong Pneumatology, but presents a strange contradiction. In all of their temples one can find the motto 'Jesus Cristo é Senhor' - 'Jesus Christ is Lord', but in practical terms it is a Spirit-driven church, not a Christ-driven church. So, there is no emphasis at all in the Nachfolge, discipleship, the following of Jesus in daily life. Therefore, the Universal Church (as it is known in Brazil) makes a weird 'reduction', a downshifting of the person and work of Christ, who is no longer presented as the Lord of all spheres of life, but as a mighty spiritual being that is obliged to do everything people ask of him, as long as, as it was already stated, the people contribute regularly to church with their tithes and offerings. From Bonhoeffer and with Bonhoeffer we learn about the Christ who suffered and in this way he reveals God to us, and at the same time, the risen Christ who is our companion on the road of life.

15 The technical and critical bibliography about Neopentecostalism in Latin America is vast. Among many one can cite Campos, Leonildo Silveira. Teatro, templo e mercado: organização e marketing de um empreendimento neopentecostal. Petrópolis e São Paulo: Vozes/Simpósio/UMESP, 1997. Mariano, Ricardo. Neo-pentecostais: sociologia do novo pentecostalismo no Brasil. São Paulo: Loyola, 1999. Pieratt, Alan B. O Evangelho da Prosperidade. São Paulo: Vida Nova, 1993. Siepierski, Paulo D. "Pós-pentecostalismo e política no Brasil”. Estudos Teológicos. Rio Grande do Sul: IECLB v. 37, n 1, pp. 47-61, 1997.

16 Bonhoeffer, Ethics, op. cit., p. 341. 
To quote him once more, 'the more exclusively we recognize Christ as our Lord, the more will be disclosed to us the breadth of Christ's lordship. ${ }^{17}$ Latin American Evangelicalism needs such a sound Christology as that which Bonhoeffer understood and taught.

\section{The integral aspect of pastoral and academic labour}

In Latin America there has been a strange dissonance, so to speak, between two tasks, viz., pastoral and academic labour. It is very easy to find, among Evangelicals and Pentecostals alike, those who call themselves only "pastors". By and large they are very proud of saying that they are not theologians. Even nowadays among Pentecostals it is still very common to quote 2 Corinthians 3:6, 'For the letter kills, but the Spirit gives life' (NIV). The popular interpretation of this verse is in the sense that the 'letter' means academic formation. On the other hand, some professional theologians have not respected pastoral practice at all. Some of them are highly skilled in several academic disciplines, but they do not preach anymore. Besides, there is a sort of strife between the theologically trained and those who are not. Both are proud of their respective positions. The fact is that this is a strange situation. In the early Church the so called Church Fathers were deep thinkers but they were pastors as well, and as such they cared for their 'flocks'. In the Middle Ages it was not much different, as was the case with the Reformers. It was only during the so called 'Modernity' that a divorce happened between the church and the academy.

But there were some notable exceptions. Dietrich Bonhoeffer was one such exception. He was a brilliant theologian. One example of his genius is that he wrote his Sanctorum Communio when he was only 21 or so. Yet, throughout his career, he never abandoned the pastoral side of his ministry. He was always a cura d'almas, a pastoral caretaker. His pastorates in Berlin, Barcelona and London, the time he spent with the brethren of Abyssinian Baptist Church in New York, and his concern with the academic and spiritual formation of the seminary students of the Bekennende Kirche in Finkenwalde give an eloquent testimony of a pastoral heart that always beat strongly, especially for those on the 'underside of history'. In Latin

17 Bonhoeffer, Ethics, op. cit., p. 344. 
America, 70 years after his martyrdom, we need to learn urgently from and with Bonhoeffer to (re) unite again what for centuries was not divided - the calling of both the academic and the pastoral. It is very common in Latin American theology - at least that of a progressive evangelical ${ }^{18}$ tune - to refer to itself as a 'Reflection on the way'19. Therefore, to use this metaphor of the road, it must be said in Latin America today that this conflict between those who privilege only the academic and those who privilege only the pastoral work must be left behind. Bonhoeffer gives us a wonderful example of how to be a theologian without forgetting the pastoral dimension of the Christian calling in the world.

Relating to this question, it is important to listen to Bonhoeffer himself. It is a quite long quotation, but it is worth citing in full:

One should not think it necessary to wait for particular experiences of 'being called' to ministry. A student who is simply gripped by the subject matter of theology and cannot turn away from it can consider that a calling. But certainly, it must be what theology is really about that enthrals the student - a real readiness to think about God, the Word, and the will of God, a 'delight in the law of the LORD' and readiness to meditate on it 'day and night'; a real willingness to work seriously, to study, and to think. It is not the experience of a call but the determination to do sober, earnest, and responsible theological work that is the gateway to the study of theology.

One may bring to theological studies one's own passions, one's philosophical, ethical, pedagogical, patriotic, or social zeal. These belong to the student as a whole person, and one must truly enter into theology with one's whole self. The person who is not driven to

18 In the North Atlantic world there is a sharp division between 'Progressive Protestantism' on one side and 'Evangelicalism' in the other. But such a division makes no sense in Latin American context. See for instance the whole of the work of Orlando Costas and the CELEP - Centro Evangélico Latinoamericano de Estudios Pastorales - and its Brazilian branch, the CEBEP (Centro Evangélico Brasileiro de Estudos Pastorais) in the last three decades of the late century - they always defined their own identity as 'Progressive Evangelicals', in clear distinction from Fundamentalist Protestantism.

19 See for instance Reflexões no caminho, the theological journal of the aforementioned CEBEP. 
theological study at least in part by these passions will certainly be a poor theologian. But theological students must then learn and know that the driving force in their lives and thinking, as theologians, can only come from the passion of Jesus Christ, our crucified Lord. The study of theology cannot be conquered by the overflowing vitality of one's own passion; rather, the real study of theologia sacra begins when, in the midst of questioning and seeking, human beings encounter the cross; when they recognize the endpoint of all their own passions in the suffering of God at the hands of humankind, and realize that their entire vitality stands under judgment. This is the great turnaround, which for the course of study means the turn toward theological objectivity. Theological study no longer means revealing the passions of one's ego; it is no longer a monologue, no longer religious self-fulfilment. Rather, it is about responsible study and listening, becoming attentive to the Word of God, which has been revealed right here in this world; it is toning down one's self in the face of what is far and away the most important matter.

[...] Finally, one should know as a true theologian that, even where our knowledge of the gospel of Jesus Christ in its truth and purity keeps us away from false doctrines, we stand beside our brethren who have wandered and been misled, sharing their guilt, interceding and praying for them, knowing that our own life depends, not on our better knowledge or being on the right side, but on forgiveness. ${ }^{20}$

\section{The importance of the confessional heritage $e^{21}$}

Dietrich Bonhoeffer, as all of us know, was a Lutheran pastor and theologian. As such, he mentioned Luther in a lot in his writings. He did

20 Bonhoeffer, Dietrich 2009. Berlin 1932-1933. Dietrich Bonhoeffer Works, Volume 12. Minneapolis: Fortress Press. p. 432-433, 435.

21 When one speaks about Bonhoeffer and confessional heritage it is practically mandatory to remember the Barmer Theologische Erklärung (Barmen Theological Declaration of 1934). Although it was written in a very particular historical context, one that is quite different from Latin American historical context of today, the lesson given by those who accepted the text of Barmen as a theological orientation for life still remains important and necessary, as an example of commitment to the lordship of Christ in all areas of life. For details of formulation of the Barmen Theological Declaration see, inter alia, 
know Luther's texts very well ${ }^{22}$. See for instance the interpretation of the Psalms in his Prayerbook of the Bible - Die Psalmen - Das Gebetbuch der Bibel, which is typically Lutheran. We also know that Bonhoeffer was personally involved in the formation of pastors of the already mentioned Confessing Church. However, with Bonhoeffer we do not learn that we must turn to become Lutherans, but we do learn the importance of confessionality, or the importance of confessional heritage. In Latin America today, there is a predominance of Pentecostalism in almost all traditional Protestant and Evangelical traditions. Nowadays in Brazil one will find signs of such a 'Pentecostalization' or 'Neopentecostalization' among Methodists, Baptists, Congregationalists, and some Presbyterians as well. Because of this influence, many traditional Protestants are leaving behind one of the most precious aspects of their Reformed heritage, namely, that is the Protestant ethics - that is an ethics of positive social influence, and not a selfish personal ethics characterized by a concern for getting rich, as Neopentecostalism teaches. From this we conclude that the life and practice of Bonhoeffer teaches us to give due value to our respective confessional traditions. Lutherans must know Luther's writings and be real Lutherans, Presbyterians must know Calvin and so many other important Reformed theologians, and Methodists must know John Wesley and be real Methodists, and so on. Our respective confessional heritages are important. They are not perfect, absolutely not, they are not sacred, of course not, but we need to (re-)discover them and give them the importance they deserves. Therefore, as far as I can understand it, Bonhoeffer teaches us Latin Americans to be 'proud', so to speak, of our respective confessional traditions. Proud, not arrogant. Proud but open to dialogue with 'the other'. Proud, but with hearts, eyes, minds and ears open to listen, to see and to understand what 'the other' has to say and to show us. Proud, but at the same time humble to confess that we need the 'other' who belongs to a tradition different from our own. This leads us to our next step.

Silveira, Julio Cesar. Igreja: vocação para a desobediência. Uma leitura da Declaração de Barmen feita a partir da teologia de Karl Barth. Curitiba: Prismas, 2014, p. 23-103.

22 About the place of Luther in the theology of Bonhoeffer see, inter alia, Krötke, Wolf 2008. Dietrich Bonhoeffer and Martin Luther. In Frick, Peter (Ed.). Bonhoeffer's Intellectual Formation. Tübingen: Mohr Siebeck. p. 53-82. 


\section{The role of ecumenism}

It is not an overstatement to say that Bonhoeffer was a confessional Lutheran theologian. Nevertheless, he was very aware of the importance of what John Mackay, 'the Scott with a Latin soul'23 called 'the science of the Church universal $^{24}$. To refer once more to his doctoral dissertation, Bonhoeffer did believe in Sanctorum Communio, the communion of the saints. It is possible to state that for Bonhoeffer one of the possibilities of living Credo in Sanctorum Communio - 'I believe in the Communion of Saints' was to keep in creative tension the confessional heritage on one hand and the importance of ecumenism on the other. It is not a coincidence that Bonhoeffer was an active forerunner of the ecumenical movement in Europe, just before the War, in some organizations that were predecessors of the WCC. His visit to Rome when he was still very young, the way he modelled the theological seminary of the Confessing Church in Finkenwalde more or less according to a Benedictine style, his aforementioned participation in the Abyssinian Baptist Church in New York (an absolutely unusual decision, considering he was a white man, a Lutheran from the highest rank in the German society of his day, and nevertheless he was among poor Black Baptist Americans), all of this gives testimony to the importance of ecumenism in Bonhoeffer's life and theology. ${ }^{25}$ Therefore, it is not a coincidence that so many scholars are approaching Bonhoeffer from the perspective of ecumenism and its role in his life and theology. ${ }^{26}$ As a matter of fact, Bonhoeffer was an ecumenist and, as will be demonstrated later, he thought about ecumenism in a theological way. As Bonhoeffer said, '... I believe in the principle of our universal Christian brotherhood which rises above all national interests...27

The question of ecumenism is not an easy one in the Latin American context. On one hand there is a history of ecumenism that is almost as

23 Cf. Sinclair, John. John A. Mackay: um escocês com alma latina. Manhumirim: DIDAQUÊ, 1995.

24 Mackay, John A 1964. Ecumenics: The Science of the Church Universal. Upper Saddle River: Prentice Hall.

25 For details see Bonhoeffer, Dietrich 2012. Ecumenical, Academic and Pastoral Work: 1931-1932. Dietrich Bonhoeffer Works, Volume 11. Minneapolis: Fortress Press.

26 See for instance, Clements, Keith. Dietrich Bonhoeffer's Ecumenical Quest 2015. Geneva: WCC Publications.

27 Apud Clements, op. cit, p. 1. 
old as the world ecumenical movement itself. See for instance the ISAL movement - Iglesia y Sociedad/Igreja e Sociedade ('Church and Society') in Latin America in the 50's. As early as in the post-WW2 period there was a concern among some Latin American Protestant leaders and thinkers, like the Methodist Argentinian theologian José Miguez Bonino, the Uruguaian Methodist theologians Julio de Santa Ana and Emilio Castro (the very first Latin American to be appointed as a Secretary to the World Council of Churches) and the Brazilian Presbyterian theologian Rubem Alves, to name only a few. ${ }^{28}$ ISAL had the concern to create a social consciousness in the mentality of Latin American Protestantism. ${ }^{29}$ But at the same time there was, and still there is, among the majority of Latin American evangelicals a strong resistance to the ecumenical movement. In Latin America the ecumenical movement is not very large, strong and influential. The CLAI Latin American Council of Churches - is not such a big organization. The majority of Evangelicals in Latin America have a distorted understanding of what ecumenism really is. In the Latin American Evangelical common sense, and for many of their leaders as well, the word ecumenism means something to be avoided at any cost, because it is considered a curse word. For almost all Evangelicals in Latin America, ecumenism is a work of Satan, created in the offices of hell to destroy the true Christian church in the world. This is obviously a caricature of what true ecumenism is and stands for. So, in such a context it would be helpful to pay attention to Bonhoeffer once more. Bonhoeffer can teach Latin Americans what true ecumenism is. He was an active member of the young ecumenical movement, as a member of the World Alliance for Promoting International Friendship through the Churches. In a very well known address delivered in Czechoslovakia in 1932, entitled 'Concerning the Theological Foundation of the Work of World Alliance', Bonhoeffer raises a very important question: How does the work of the ecumenical movement appear in the light of the truth of

28 For a concise but at the same time detailed history of ecumenism in Latin America, see Cunha, Magali do Nascimento. "Quero trazer à memória o que me pode dar esperança". Movimento ecumênico: avaliação e perspectivas. Numen. 21, V. 1, N. 1 e 2, 2010, p. 103 135.

29 For the history and proposals of ISAL see Bittencourt Filho, José. Por uma eclesiologia militante. ISAL como o nascedouro de uma nova eclesiologia para a América Latina. Dissertação de Mestrado em Ciências da Religião. São Bernardo do Campo: Instituto Metodista de Ensino Superior, 1988. 
the gospel? ${ }^{30}$ According to Bonhoeffer, the church, as the one congregation of the Lord Jesus Christ, who is the Lord not of the church only, but of the whole world, to speak the word of Christ to this world. It is this claim of Christ on the whole world that unifies the churches and defines their task. Bonhoeffer correctly declares that the authority of the church to speak to the world is the authority of the present, living Christ. The church in the theology of Bonhoeffer is 'Christus praesens', Christ present. Therefore, the word of the church to the world has authority because it is the word of Christ who is present. ${ }^{31}$ Bonhoeffer offers a sound theological foundation for understanding 'ecumenismo' and its proposal to the world. This theological comprehension provided by Bonhoeffer of the ecumenical task of the church in the world is highly needed in Latin America, 70 years later after his execution in the Nazi gallows.

So, for us Latin Americans it is very important to learn from and with Bonhoeffer that the Christian heritage is a wide and rich mosaic and no one can dare to claim the plain truth about everything.

\section{A church that is oriented to the other, not to itself}

Bonhoeffer was a systematic theologian with specific focus on ecclesiology, but, as we have seen, his ecclesiology was based on and derived from his Christology. Therefore, the logical consequence of this Christ-based ecclesiology was that he concluded that the Church must exist for the sake of the other, and not to herself. This is an urgent lesson for us in Latin America. Latin American ecclesiology is, allow me to say, quite a mess. I will try to present a brief survey of the churches in Latin America today: Some churches are like oysters living in a shell, closed to themselves with absolutely no contact with those outside its walls. Other churches think only in terms of numerical growth. This is a sort of 'autophagy', as the church in this way lives only for herself. This ecclesiological model understands the mission of the church only as evangelization, 'winning souls for Jesus', as they like to say. Other churches (the already mentioned Neopentecostal

30 Cf. Bonhoeffer, Dietrich 2012. Ecumenical, Academic and Pastoral Work: 1931-1932. Dietrich Bonhoeffer Works, Volume 11. Minneapolis: Fortress Press. p. 356-369.

31 Cf. Godsey, John D 2015. The Theology of Dietrich Bonhoeffer. Eugene: Wipf and Stock Publishers. p. 97-98 (previously published by Westminster Press, 1960). 
churches) are concerned only with taking money from those who go to their meetings - there is no longer any form of traditional membership, nor any ecclesiastical life. What does exist is only an endless sequence of 'chains of prayer' (correntes de oração), where prayer is presented as a magic key to open the doors of heaven and a tool to oblige God to do what we want. In such a complicated scenery, it will be wise to (re)learn the understanding of church and its purpose according to Bonhoeffer (in Letters and Papers from Prison) - 'Die Kirche ist nur Kirche, wenn sie für andere da ist.' 'The church is church only when it is there for others.' ${ }^{32}$ In Sanctorum Communio he said: 'The church is the presence of Christ in the same way that Christ is the presence of God'. ${ }^{33}$ Christ Jesus is the supreme model of living for others, not for himself. So must live the Church. Thinking about Bonhoeffer's understanding of how the church must be, Prof Brigitte Kahl said:

It is precisely and in particular the Christ event of incarnation, crucifixion and redemption that requires us to accept our solidarity with them, who we had thought were the sinners, the outsiders, the non-us: Jews, Catholics, heretics, Muslims, unbelievers...

\section{Concluding remarks}

This essay presents some conclusions of what we in Latin America, both Spanish-speaking and Portuguese-speaking, have to learn from and with Dietrich Bonhoeffer. Five points were mentioned:

1. The centrality of Christology in theological reflection.

2. The integral aspect of pastoral and academic labour.

3. The importance of the confessional heritage.

4. The role of ecumenism.

5. A church that is oriented to the other, not to itself.

32 Bonhoeffer, Dietrich 1998. Ethik. DBW (Dietrich Bonhoeffers Werke), Band 6. Güttersloh: Güttersloher Verlaghaus. p. 560.

33 Bonhoeffer, Dietrich 2009. Sanctorum Communio. A Theological Study of the Sociology of the Church. Dietrich Bonhoeffer Works, Volume 1. Minneapolis: Fortress Press. p. $140-141$. 
Certainly there are more points that could be mentioned. However, what was presented is sufficient to demonstrate that we in Latin America still have much to learn from and with Bonhoeffer. To paraphrase a famous statement by Karl Barth about John Calvin, let us keep following, not Dietrich Bonhoeffer, but He who was the master of Dietrich Bonhoeffer. 